\title{
Katasztrófavédelem, biztonságpolitika és a területfejlesztés
}

\author{
Disaster management, spatial planning and regional \\ development
}

\section{SZABÓ MÁTYÁS}

KULCSSZAVAK: katasztrófavédelem, területrendezés, területfejlesztés, biztonságpolitika, védelem, biztonság, stratégia

\begin{abstract}
ABSZTRAKT: A biztonságpolitika-elméletben az utóbbi időszakban egyre elfogadottabbá vált a biztonság fogalmának tág értelmezése, amelyben nem csupán a korábbi, katonai típusú kockázatok szerepelnek, de olyan más összetevők is, amelyeket a társadalmi, ökológiai, gazdasági biztonság körébe lehet sorolni és amelyeket a biztonságtudomány a kockázatok jellemzői alapján rendszerbe foglalt és pontosan csoportosított. A tanulmányban bemutatom, hogy bár a biztonságpolitika hazánk szempontjából releváns szereplői (NATO, EU, USA, Egyesült Királyság, Magyarország) átvették a tág értelmezést, a biztonsági stratégiákban ezeknek az új kockázatoknak a kezelésére nem tesznek kísérletet, és még csak meg sem határozzák, hol, mikor, hogyan, kinek a feladata az adott tényezőre irányuló fejlesztési tevékenység. Ezzel párhuzamosan látható, hogy a területfejlesztési és területrendezési tervek sem ismerik fel/el ezen - amúgy fejlesztendőnek tekintett - elemek biztonságpolitikai fontosságát, holott a biztonság horizontális célok közé való emelésével megalapozottabb, komplexebb fejlesztési dokumentumok készíthetők, mert egy új szemponttal lehet erősíteni a beavatkozások indokoltságát, valamint a fejlesztésekbe a biztonságpolitika számára elérhető eszközrendszer is bevonható. A biztonságpolitika és a területi tudományok összekapcsolását a katasztrófavédelem adhatja meg, amelyben a „civil” területi egységek éppúgy megjelennek, mint a biztonsági tényezők. A cikk a címben szereplő három szakma összekapcsolásának megalapozásához kíván hozzájárulni.
\end{abstract}

KEYWORDS: disaster management, land-use planning, spatial planning, regional development, regional planning, security policy, defense, security, strategy

ABSTRACT: In March 2013, weather conditions (extreme snow storm) in Hungary were such that they exposed the weakness of co-operation between disaster management, spatial planning and regional development institutions and planning. The ineffective management of the situation by the territorial units and professional (police, fire brigade, etc.) organisations caused such a chaos on some of the Hungarian motorways that thousands of people had to wait long hours (in some cases, up to 40 hours) in their cars, under the snow, for rescue units to reach them. Their areas of responsibility either overlapped or were totally incongruent. If the plans of a motorway would provide for parallel swaths of land on both sides of the motorway (which they don't due to financial constraints - which in turn are an issue of regional development and spatial planning)

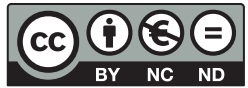


so that hedges protecting against snow-drift could be planted, the snow could not pile up so high on motorways. If the various organisations had co-operated better or at all, both rescue efforts and disaster prevention would have been more effective.

A wider understanding of the definition of security has become increasingly accepted in security theory recently. It focuses no longer only on military-related risks but also on other risk components. These can be identified in the spheres of social, ecological and economic security which have been systematised and categorised precisely by the science of security based on the characteristics of the various risks.

This study aims to demonstrate that although the actors of security policy (NATO, EU, USA, United Kingdom, Hungary) have accepted the wider understanding of their security strategies, they do not try to deal with these new risks and do not even define who will be responsible for which development activity.

It is obvious that neither regional development plans recognise or admit the importance of these otherwise generally considered necessary elements of security policy to be developed. As security among EU horizontal objectives is being raised, more valid and more complex development plans can be drawn up, because the validity of interference can be strengthened with a new point of view and the already available set of tools for security policy can be included for the benefit of further development.

The connection between security policy and regional sciences can be made by disaster management. In this field "civil" spatial units and security risks can be integrated. This article is intended to contribute to building stronger connections between the three fields.

\section{Bevezetés}

Közhelynek számít, de világunk egyre bizonytalanabb, egyre kiszámíthatatlanabb. Ez megjelenik az egyén szintjén, annak életvitelében, de a társadalom más szintjein is, gondolhatunk itt akár térségre, országra, földrészre. Ehhez hozzájárulnak az egyre összetettebb folyamatok, amelyek nehezítik a résztvevők (vezetők, tervezők, szakértők stb.) előrelátását. ,Jó” példa erre a cikk lektorálása közben kialakult 2013. március 15-i hazai hóhelyzet. Az események sajnálatos módon jól mutatják a címben szereplő három szakma elkülönülését és ennek következményeit. Egyfelől a katasztrófavédelem ágazati - pl. a katonasággal, rendőrséggel való - együttműködésének hiánya, illetve a területi - helyi és regionális szintü - szervezetekkel való gyenge kapcsolata csökkentette a mentés, a megelőzés, a kommunikáció hatékonyságát. Másfelől rámutat a katasztrófavédelem, biztonságpolitika és területfejlesztés általános, „hétköznapi” összehangolásának szükségességére (esetünkre konkrét javaslat, hogy a területfejlesztési beruházások - sztrádaépítés - során legalább akkora területtel kell számolni, amely szükséges a 2009. évi XXXVII., Az erdőről, az erdő védelméről és az erdőgazdálkodásról szóló törvényben meghatározott mütárgyvédelmi véderdo” kialakitásához. ${ }^{1} \mathrm{~A}$ törvény szerint a mütárgyvédelmi véderd” „az utak és mütárgyaik (...) védelmét, takarását, a közlekedés biztonságát szolgáló, a környezeti terhelést csökkentő erdő". A területrendezés és -fejlesztés hazai gyakorlatában a vonalas infrastruktúrák véderdőivel újabban ritkábban találkozhatunk (bár azok a múltban nálunk is elterjedtek voltak, a fejlett országokban pedig használatosak esztétikai, ökológiai előnyeik miatt), pedig a véderdő képes az utakon közleke- 
désből keletkező szennyező anyagok részleges helyben tartására (Fi 2002) vagy fordítva, megvédheti az utat a külső (hó, por stb.) hatásoktól (megakadályozhatta, csökkenthette volna a több méter magas hófalak kialakulását, mivel egy erdősáv képes - még lombtalanul is - lassítani a szelet, illetve felfogni a hó egy részét) (http://kertesz.blog.hu).

Az egyre növekvő általános bizonytalansági folyamat egyik fontos következménye, hogy a jövőbe fektetett bizalom (Hideg, Nováky 2008) gyakran még az egyén szintjén is csökken. Másik természetes velejárója a biztonság általános felértékelődése, amellyel kapcsolatban többek között felmerülhet az a kérdés is, hogy a biztonság és az annak kezelésére hivatott biztonságpolitika miként, milyen szálakon kötődik a fejlesztéspolitikához. A kérdés - illetve az arra adható válasz - annál is izgalmasabb, mivel a biztonság, a biztonságpolitika alig vagy egyáltalán nem jelenik meg a jelenlegi területfejlesztésben, és hiánya csak akkor érzékelhető a nyilvánosság számára is, ha valamilyen természeti vagy gazdasági katasztrófa rávilágít arra. Az írás célja bemutatni, hogy megalapozott területfejlesztés elképzelhetetlen a biztonsági tényezők átfogó és koherens figyelembevétele nélkül, mivel a biztonságpolitikai kockázatok, tényezők komplex rendszert alkotnak, és a területiséggel való kapcsolatuk nyilvánvaló (1. táblázat).

A fenti tényezők esetében a biztonság különösen hangsúlyossá válik, ha magas népsűrűségű területről van szó, ahol időben párhuzamosan több, egymást erősítő tényező léphet működésbe (pl. egyidejü árvíz- és járványveszély szinergikus hatásai).

Ahhoz, hogy érthetővé és érzékelhetővé váljék a biztonság kérdésének kezelése, bemutatom a biztonságfogalom változásait, valamint a területiség, a fejlesztési rendszerek és a biztonságpolitika összefüggéseit.

1. táblázat: A biztonsági kockázatok csoportosítása

Classification of security risks

\begin{tabular}{|c|c|}
\hline Szempont & Csoportok \\
\hline A kockázat jellege & katonai (kemény), nem katonai (puha) \\
\hline A kockázat időtartama & egyszeri, rövid távú, középtávú, hosszú távú \\
\hline A kockázat időpontja & $\begin{array}{l}\text { közvetlen (azonnali reagálás), távlatban jelentkező (szervezetten } \\
\text { felkészülhető) }\end{array}$ \\
\hline A kockázat alanya & egyén, csoport, ország, állam, nemzet \\
\hline A kockázat eredete & $\begin{array}{l}\text { társadalmi (egészségügyi, szociális) - pl. járványkockázat; leszakadó rétegek, } \\
\text { társadalmi csoportok marginalizálódása; etnikai konfliktusok stb.; } \\
\text { gazdasági (energetikai, informatikai, pénzügyi) - pl. nemzetgazdaságok } \\
\text { összeomlása; nemzeti önellátás biztosítása; nyersanyagellátási nehézségek; } \\
\text { kereskedelmi útvonalak; kiberbiztonsági kockázatok stb.; } \\
\text { ökológiai (levegő, talaj, víz) - pl. klímaváltozás hatása a lakosságra, } \\
\text { természeti erőforrások biztosítása, gyengülő biodiverzitás hatása az } \\
\text { élelmiszertermelésre stb. }\end{array}$ \\
\hline Területi dimenziói & $\begin{array}{l}\text { globális, nemzetközi, makroregionális, nemzeti, szubnacionális, helyi, } \\
\text { települési }\end{array}$ \\
\hline
\end{tabular}




\section{A biztonságpolitika értelmezése és összefüggései}

A biztonság átfogó fogalom, amely mindig valamilyen érték, értékek ellen irányuló fenyegetés, veszély vagy kockázat megjelenése kapcsán felmerülő igény (Gazdag 2001). A biztonságpolitika az adott érték kockázatának csökkenése vagy erősödése ellen tett lépéseket, tevékenységeket foglalja magába. A biztonság szó a latin sine cura („gond nélkül”) kifejezésből ered. Korábbi egyértelmű, letisztult fogalmát az 1940-es évektől használták a nemzetközi kapcsolatokban. Ebben az időszakban olyan fogalomként definiálták, amely szorosan kötődik az államok közötti konfliktusokhoz, a fegyveres erővel való fenyegetéshez, a fegyveres erő alkalmazásához és ellenőrzéséhez. „A biztonságnak ezt a szűk, hagyományos - katonai és államközpontú - szemléletét az 1970-es évek végén és az 1980-as években érték az első komoly kritikák" (Gazdag, Tálas 2008, 355.). A korábban pusztán katonai tartalmú kérdések mellett új, „külső” hatások jelentek meg, amelyek „rést ütöttek a pajzson”. Gondoljunk csak az olajválságra és az annak nyomán felmerülő - napjainkra a nemzetközi kapcsolatok markáns részét képező - energiabiztonsági kérdésekre vagy az üvegházhatás kapcsán egyre inkább felértékelődő környezetbiztonságra. Az új - 21. századi - biztonsági kihívások eredményeként a biztonságpolitika határai jelentősen kibővültek. Az ágazati koncentráció jegyében már a biztonság sem képzelhető el társadalmi, gazdasági és ökológiai biztonság nélkül (Buzan, Wæver, de Wilde 2006).

Gazdag Ferenc (2001) és Deák Péter (2007) munkája alapján ezeket a területeket az alábbiak szerint lehet összefoglalni:

- a politikai biztonság az állam belső stabilitásával, általános szuverenitási fokával mérhető;

- a gazdasági biztonság az állam adósság- és nyersanyagfüggőségét, monetáris mozgásterét, nemzetközi integrációs konvergenciakövetelmények teljesíthetőségét jelenti;

- a technológiai biztonság az infrastruktúra épségét követeli meg, valamint a fenntartható fejlődés feltételeinek biztosítását és a kutatás-fejlesztési, technológiai fejlődés keretét is jelentheti;

- szociális biztonság alatt a kiegyenlített társadalmi helyzetet értjük, amelyben a különböző csoportok (demográfiai, földrajzi, gazdasági stb.) között szolidaritási mechanizmusok müködnek;

- az ökológiai biztonság fogalmába beleértjük a természeti eredetűek mellett az emberi kockázatokat is, például ipari katasztrófahelyzeteket;

- egy állam belső biztonságát jól jellemzi még a közbiztonság állapota (az állampolgárok is ezzel a tényezővel érintkeznek a legközvetlenebbül), a bűnözés elterjedtsége;

- a katonai vagy védelmi biztonság fogalmának negatív definíciója szerint, „akkor beszélhetünk katonai biztonságról, ha nem áll fenn közvetlen, külső katonai fenyegetés." (Gazdag 2001). 
Ezt a tág fogalomértelmezést írja le a biztonságpolitikai szakma új elméleti iskolája a „biztonságossá tétel” (securitisation, amely Dudás szóhasználatában „biztonságiasítás”) kifejezéssel (biztonsagpolitika.hu). A fenti példák önmagukban súlyos kockázatokat rejthetnek, és a történelem több alkalommal bebizonyította, hogy számos eleméből következhet tömeges migráció, eszkalálódó vagy új fegyveres konfliktus. E szektorok megjelenésével párhuzamosan bővült a biztonságpolitika szereplőinek köre is, ami rámutatott a korábbi államközpontú felfogás másik gyengeségére. Ma már egyértelmű jelei vannak, hogy a nemzetközi szervezetek (pl. Amnesty International), a multinacionális vállalatok (pl. British Petrol) és az állam nélküli nemzetiségek (pl. kurdok) fontos szereplői a biztonságpolitikának.

\section{A területfejlesztés elemeinek megjelenése a biztonságtudományban}

A különböző elméleti megközelítések tehát jól láthatóan foglalkoznak a biztonság fogalmának bővülésével, ugyanakkor kevés helyen jelenik meg a szakirodalomban, hogy ezen elemek megegyeznek a fejlesztéspolitikában is kezelt kérdéskörök egy részével. A két terület átfedéseinek, összefüggéseinek gyakorlatorientált feltárására tesz kísérletet a tanulmány további része.

A vizsgálat a hazánk számára legfontosabb szereplők biztonságpolitikai alapdokumentumainak ${ }^{2}$ áttekintésével az alábbi kérdésekre kereste a választ: A tanulmányozott dokumentum

1. A biztonságpolitika tág értelmezését veszi-e alapul?

2. A biztonság új elemeit külső tényezőként kezeli vagy a biztonságpolitika által kezelendő területként?

a. Ha külső tényezőként, kijelöli-e az elem helyét más struktúrában?

b. Ha belső tényezőként, valóban teljes körüen, a kockázatok felmérésével vizsgálja-e azt? Vizsgálata kiterjed minden lehetséges elemre, vagy csak néhányat emel ki?

3. Egyenrangúan kezeli-e a kemény és a puha (új) elemeket?

4. Milyen - esetleg a területfejlesztéssel azonos - területi egységekben "gondolkodik" a biztonságpolitikai szakma?

A fenti szempontrendszer alapján a következő általános megállapítások fogalmazhatók meg:

1. A fejlesztési dokumentumok átvették a fogalom bővülését, de az új tartalmi elemeket csak a biztonság külső, környezeti elemeként vagy globális kihívásként kezelik, nem pedig fejlesztendő vagy beavatkozásra szoruló kérdésként. Erre még az sem indok, hogy a biztonságpolitikai nemzetközi szervezetek többségének - NATO, Európai Biztonsági és Együttműködési Szervezet, a korábbi Nyugat-európai Unió - fő profilja 
vagy egyértelműen a biztonság katonai vagy politikai dimenziójához köthető, vagy egyáltalán nem az (pl. EU). Ha ugyanis elfogadjuk, hogy a biztonság tág fogalom, akkor erre egy biztonsági szereplő nem adhat csupán katonai válaszokat, meg kellene jelölnie legalább, hogy ki (más) felelős az adott nem katonai témáért. Ezzel ellentétes helyzetet tapasztalunk, ha az EU anyagait tanulmányozzuk. Az önálló közös külés biztonságpolitika megjelenése előtti és utáni koncepciókat áttekintve megállapítható, hogy bár léteznek uniós katonai, informatikai, energiabiztonsági stb. stratégiák, a biztonsági szempontok mint horizontális elvek számottevően nem jelennek meg más ágazati vagy fejlesztési politikákban.

2. A globális, a szövetségi, a makroregionális és a nemzeti szinteknél kisebb területi egységet az anyagok egyáltalán nem vizsgálnak, ráadásul ezeket is a területi tudományoktól eltérő tartalommal használják. Egyedül a nemzeti katonai stratégiákban találunk kisebb területre vonatkozó elemeket, de azok is kizárólag védelmi egységek (például a helyi, megyei védelmi bizottságok illetékességi területei).

3. A biztonságpolitika demilitarizálódását legjobban a nemzetállami biztonsági stratégiákon figyelhetjük meg. Az USA fejlett tervezői intézményrendszert tart fent azzal a céllal, hogy az ágazati terveket megfeleltesse a biztonsági kritériumoknak. Ennek meg is van az eredménye, hiszen az alig több, mint félszáz oldalas National Security Strategy megfelelő arányban szerepelteti és egyértelmüen megjelöli a szektorális problémákat és a szükséges intézkedéseket a fentiekben már jelzett új biztonsági területeken is. Az Egyesült Államok védelmét e dokumentum alapján alrendszerekre osztják fel, és ezen ágazati dokumentumok meghatározzák az adott tényezők kérdéseit. Itt kell megjegyeznem, hogy a katonai szakirodalomnak megfelelően a nemzeti védelmi tervek (pl. az Egyesült Királyságé) tartalmaznak helyi védekezési terveket, amelyek nemcsak katonai, de gazdasági-társadalmi tényezőkkel is számolnak a közvetlen védekezésbe bevonandó elemekként (pl. gazdasági és anyagi szolgáltatási kötelezettségek). Ellenpólusként hazánkra tekintve megállapíthatjuk, hogy itthon nem áll rendelkezésre hasonló tervezői apparátus, így a biztonságpolitikai alapdokumentumok - a megváltozott külső körülményeken túl - érdemben nem is foglalkoznak a „biztonságossá tétellel”. Pontosabban a legújabb hazai Nemzeti biztonsági stratégia (1035/2012. (II. 21.) kormányhatározat) az országhatáron túlmutató, nem katonai biztonsági kérdésekről kijelenti, hogy azokat az EU-NATO szövetségi rendszer keretében kívánja kezelni, így legalább a minimális elvárást teljesíti, amikor az adott tényező más rendszerbeli helyét megjelöli. 


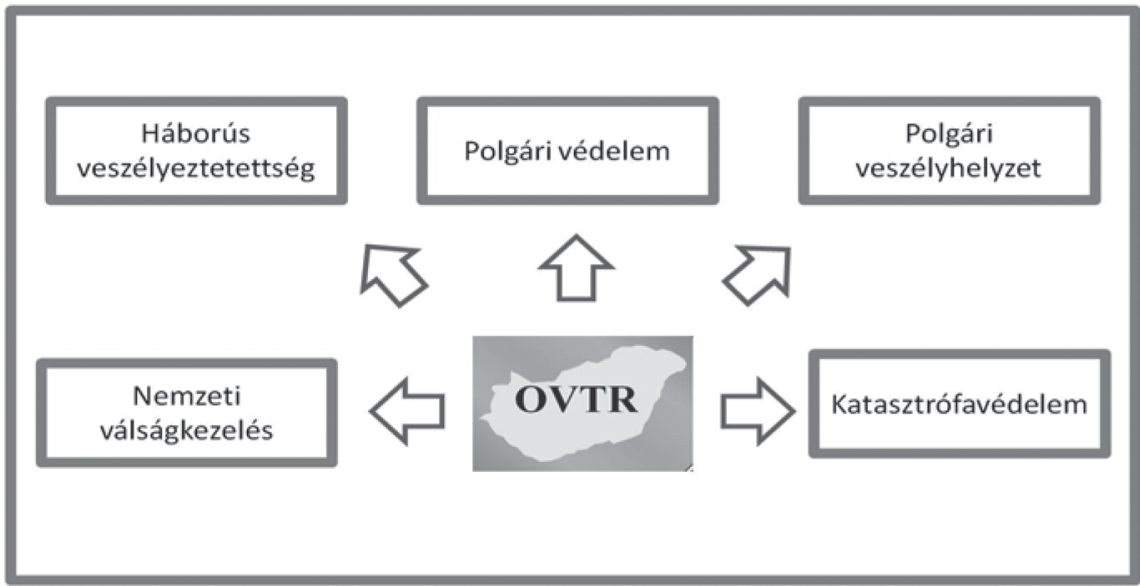

Megjegyzés: OVTR: Országos védelmi tervezőrendszer.

Forrás: Kunos 2008 alapján saját szerkesztés.

Fenti állításokat alátámasztandó érdemes áttekinteni a biztonsági tervezés módszertanát is, amely véleményem szerint megerősíti, hogy az „új” elemekkel is mélyrehatóan kellene foglalkoznia a biztonságpolitikának.

Kunos (2008) előadásában bemutatja, hogy az országvédelmi tervezés mely területekre terjed ki, amelyekhez később hozzárendeli a tervezés fázisait és a tervezés szintjeit a képesség, feladat, erőforrás és költségtervek hierarchiájában (1. ábra).

Jól látszik, hogy a hazai biztonsági szakma tervezési módszertana is szinte kötelezővé teszi a tág fogalomértelmezést, és minden elemére kiterjedően javasolja a felmérést, tervezést. Két kérdést emelhetek ki, amelyek kapcsolódási pontként szolgálhatnak a területfejlesztéshez.

1. A területi dimenzió minden biztonságpolitikai, katonai terv alapvető eleme, a „mi és hol?” központi kérdés számukra. A területiség megjelenik az infrastruktúra és más tényezők feltérképezésében (nem véletlen, hogy a térinformatika és a GPS-alapú rendszerek első alkalmazói a katonai szervezetek voltak) vagy a kockázatok várható megjelenésében (a kockázatok és a területi dimenzió összekapcsolódásáról lásd az 1. táblázatot).

2. Az országvédelem kiterjed a lakosságra és az infrastruktúrára. Ez utóbbi esetében a területrendezés számára is ad feladatokat, hisz a térhasználatot a védelmi előírások is befolyásolják. Mikroszinten ez jelenti az egyes épületek, műtárgyak építési szabályzataiban megjelenő előírásokat, míg mezo- és makroszinten a várostervezésnél és az infrastruktúrahálózat tervezésénél játszik fontos szerepet. 


\section{A biztonságpolitika megjelenése a hazai területfejlesztésben}

A magyarországi helyzet jól rávilágít az érem másik oldalára is, miszerint a fejlesztési dokumentumok sem foglalkoznak érdemben a biztonságpolitika egészével. Ezt a kijelentést a hazai területfejlesztési tervrendszer átfogó vizsgálatával lehet alátámasztani.

A védelmi tervezéssel szemben - amely középtávú (10 éves) ciklusokban gondolkodik, a gördülő tervezés módszerét alkalmazza és parlamenti, kormányzati (honvédelmi minisztériumi), haderőnemi és intézményi szinteket ölel fel - a hazai területfejlesztési tervhierarchia többszereplős, több összetevős. A 2. ábrán látható, hogy három szinten zajlik a tervezés: országos, közép- és helyi szinten (ezek belső tagozódása is megfigyelhető). A rendszer egészét országos szinten határozzák meg, kialakító tényezői közül leginkább a területfejlesztési törvény (1996. évi XXI. törvény) és az európai uniós támogatási struktúra kiemelendő. Hazánkban sajnos a szükségesnél jobban elkülönül az uniós forrásal-

2. ábra: Tervek, intézmények és területi szintjeik egyszerüsített hierarchiája Simplified hierarchy of plans, institutions and their spatial levels

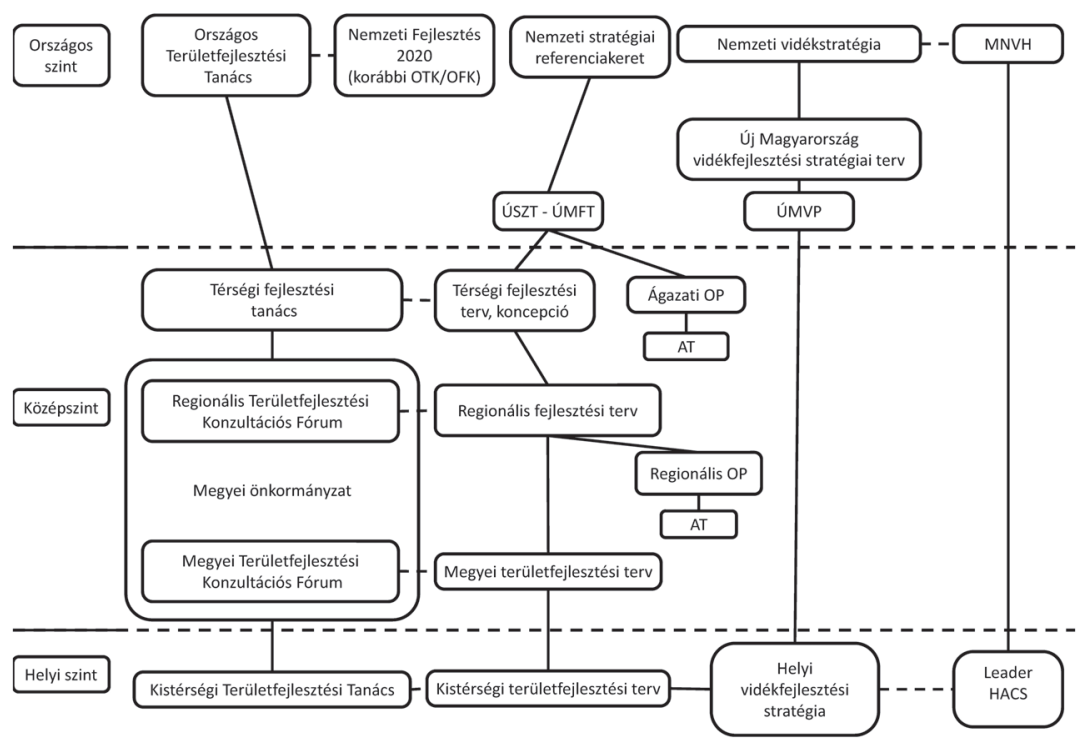

Megjegyzés: Az ábra a tervezési logikát követi a 2007-2013-as időszakban, az egyszerüsités érdekében nem mutatja a különbözö döntési hatásköröket (az elfogadás helyét - pl. Országgyülés vagy kormány), nem kezeli a tervek különböző időtávjait és a döntésben részt vevő szférák száma szerinti megkülönböztetést sem. Az ábra nem tartalmazza a járást mint területegységet, mivel az csupán közigazgatási funkciót lát el, a területfejlesztési feladatokat továbbra is a kistérség látja el. Röviditések: MNVH - Magyar Nemzeti Vidéki Hálózat; ÚSZT - Új Széchenyi-terv; ÚMFT - Új Magyarország fejlesztési terv; ÚMVP - Új Magyarország vidékfejlesztési program; OP - operatív program; AT - akcióterv; HACS - helyi akciócsoport. 
lokációs és a területfejlesztési tervezés, holott előbbinek az utóbbira kellene épülnie, így mindkettő esetében szükséges és indokolható a biztonságpolitikai szempontú vizsgálat.

Az országos szint elemzését az Országos területfejlesztési koncepcióval (OTK), az Országos fejlesztéspolitikai koncepcióval (OFK), a Nemzeti stratégiai referenciakerettel (NSRK) és a Nemzeti vidékstratégiával (NVS) kezdve megállapitható, hogy a hazai tervezésben és a területfejlesztési kereteit adó (a hierarchia többi szintjét meghatározó) dokumentumokban a biztonság fogalma nincs egységes rendszerbe foglalva, hanem szétaprózódott a 3. ábrán látható területeken. A vizsgálat alapján a következőket emelem ki:

- Az országos szint dokumentumai a foglalkoztatásnak és a versenyképességnek vannak alárendelve, a 3. ábra elemei akadályozó vagy fejlesztendő tényezőként szerepelnek.

- A dokumentumok szerint ezen elemek mindegyike kihívásként kezelendő a fejlesztések szempontjából, fejlesztendő célokként azonban egymással való kölcsönhatásaikat, összefüggéseiket nem mutatják be, holott egy egységes „,biztonsági” rendszer lehetővé tenné ezt.

- A biztonság a fenntarthatóság szinonimájaként szerepel (OTK, 13. o.).

- A kiemelt térségek fejlesztési céljainál is megjelennek bizonyos biztonsági tényezők, de továbbra sem rendszerbe foglalva.

- Egyes helyeken a biztonságpolitikáról szó esik ugyan, de mindig szúkített értelemben, mint például az Országos területfejlesztési koncepció 16. pontjában, ahol csak kemény tényezőket szerepeltetnek, vagy a Nemzeti vidékstratégiában: „Genetikai erőforrásaink felkutatása, begyűjtése, megőrzése, fenntartása és felhasználása fontos nemzetbiztonsági stratégiai kérdés." (NVS, 86.).

3. ábra: A biztonság és a vele összefüggésben felmerült témák az OTK-ban, OFK-ban, NSRK-ban, NVS-ben Security and related topics in some planning documents of Hungary

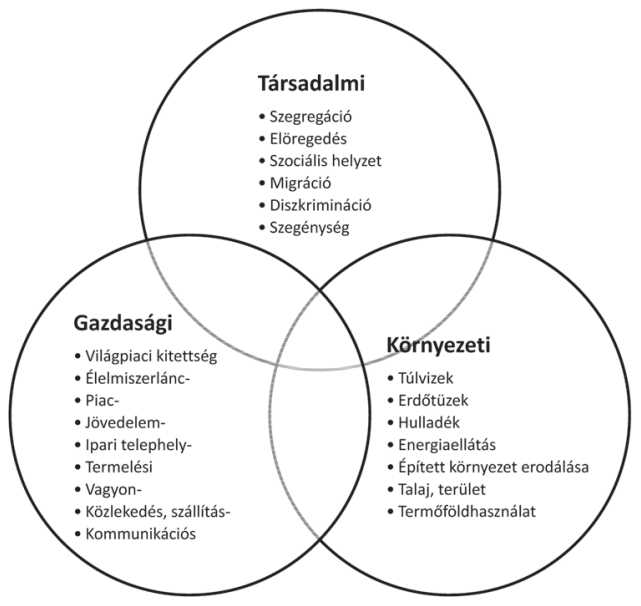


- A biztonságpolitikának még a klasszikus, katonai-védelmi elemekkel való összehangolása is hiányzik.

A jelenleg még hatályos Országos területfejlesztési koncepció és az Országos fejlesztéspolitikai koncepció új verzióját megalapozó Nemzeti fejlesztés 2020 címü, társadalmi vitára bocsátott dokumentum a fenti értékeléstől eltérő jellemzőket nem mutat, ezen szempontok alapján megegyezik felváltandó elődjeivel.

Terjedelmi okok miatt nem vállalkozom a 7 régió, 19 megye és többszáz helyi (kistérségi-járási, mikrotérségi, települési) terv bemutatására, mégis fontosnak tartom kiemelni, hogy az országos szint hatása miatt értékelhető módon sehol nem jelenik meg a biztonságpolitika összehangolása a területfejlesztési politikával. ${ }^{3}$ A szubnacionális egységek általában csupán a honvédségi területek lőszermentesítését, a laktanyák rehabilitációját, a közbiztonságot kezelik biztonságpolitikai kérdésként, pedig lehetőség lenne például a helyi honvédelmi infrastruktúra ellátására is a helyi piacok, a kereskedelem fejlesztésével. Tehát ez a terület, „holttér”, amelyben a helyzetből fakadó lehetőségek továbbgondolhatók lennének.

\section{A lehetséges összekapcsoló elem: a katasztrófavédelem}

A biztonságpolitika és a területfejlesztés közti híd elsősorban a katasztrófavédelemi szakma segítségével valósulhatna meg. A biztonságpolitika részét képező hazai védelemigazgatás ${ }^{4}$ és polgári védelem e fontos szereplője felelős ugyanis a korábban tárgyalt, tágan értelmezett lakossági biztonságfogalmi kockázatok kezeléséért és mérsékléséért. Az integráló szerep azért csak lehetőség, mert a katasztrófavédelem nem kapcsolódik szervesen sem a honvédelmi tervezéshez, sem a területfejlesztési tervezéshez. A korábban a honvédelem alá tartozó terület ma a Belügyminisztérium (BM) hatáskörébe tartozik, ami írásom szempontjából akár jó jel is lehetne, ha a minisztérium önkormányzati ügyekért felelős szerveinek tervezésén keresztül betagozódna a területfejlesztési tervezésbe is; de ez nem történik meg teljes körüen.

Ennek oka egyfelől, hogy a katasztrófavédelem elsősorban a már bekövetkezett krízishelyzetek hatásainak csökkentésére koncentrál. Nem a kockázatok csökkentése a küldetése, hanem a lehetséges kockázatok felmérése és megvalósulásuk esetén cselekmények (riasztás, mentés, biztosítás, helyreállítás stb.) megtervezése (lásd az Országos Katasztrófavédelmi Főigazgatóság alapító okiratát, amely szerint a főigazgatóság feladata „a katasztrófák elleni védekezéssel összefüggő jóváhagyott fejlesztések tervezése és felügyelete").

Ezt a leírást támasztja alá a katasztrófavédelmi törvény (2011. évi CXXVIII. törvény) is, amelyet „a lakosság biztonságának és biztonságérzetének növelése céljából, a természeti és civilizációs katasztrófák elleni védekezés hatékonyságának fokozása, a katasztrófavédelmi szervezetrendszer erősítése, a katasztrófavédelmi intézkedések eredményességének növelése érdekében" alkotott meg a 
törvényhozó testület. Ez a törvény adja meg a katasztrófavédelem definícióját is (,e törvény használatában”): a katasztrófavédelem „a különböző katasztrófák elleni védekezésben azon tervezési, szervezési, összehangolási, végrehajtási, irányítási, létesítési, működtetési, tájékoztatási, riasztási, adatközlési és ellenőrzési tevékenységek összessége, amelyek a katasztrófa kialakulásának megelőzését, közvetlen veszélyek elhárítását, az előidéző okok megszüntetését, a károsító hatásuk csökkentését, a lakosság élet- és anyagi javainak védelmét, az alapvető életfeltételek biztosítását, valamint a mentés végrehajtását, továbbá a helyreállítás feltételeinek megteremtését szolgálják". Tehát a szerteágazó tevékenységek túlnyomó részben a katasztrófa elleni védekezésre irányulnak, és csak kisebb mértékben a kockázat megelőzésére, csökkentésére. Szintén e törvény szerint a polgári védelem feladata „a veszélyelhárítási tervezés, szervezés”, így a tervezői funkciók is ezen irányban teljesednek ki. A törvény szabályai szerint a kormány feladata a tervezés „kormányszintű feladatainak végrehajtása, a katasztrófák következményeinek felszámolására való felkészülés, a megelözés, a végrehajtás és a helyreállítás feladatainak tárcák közötti koordinációja".

Az említett áthidaló szerepet gyengíti, hogy a katasztrófavédelmi tervezés készítése során a védelmi tervezést csupán bevonni szükséges, annak közremüködésével kell végrehajtani, de a területi tervezésről említést sem tesz a hivatkozott törvény. A honvédelem távoltartását erősíti (valószínúleg inkább azt elzárva a katasztrófavédelemtől) a törvény hatályának korlátja, amely szerint a jogszabály nem érinti a Magyar Honvédség vezetési-irányítási rendszerét, így annak tervezését sem. A gyenge kapcsolódás jele még, hogy egyes ügyekbe beleszólása van a katonai szervek vezetőjének (a honvédelemért felelős miniszternek), de ezek csak egyetértési jogkörök, például a polgári védelmi szervezetek összlétszámának meghatározása esetében. ${ }^{5}$ A tervezéskor viszont még egyetértési jogköre sincs más szerveknek, így a területfejlesztési intézményeknek sem.

A honvédelemmel való kapcsolatnak persze vannak a kohéziót erősítő elemei is. Katasztrófák esetén bevethetők a honvédségi erők, a szükséges létszámnak megfelelően a honvéd vezérkar fönöke, a honvédelemért felelős miniszter, illetve a kormány döntése alapján. Ilyen szervezet a Katasztrófavédelmi Koordinációs Tárcaközi Bizottság (korábbi nevén: Katasztrófavédelmi Koordinációs Kormánybizottság) is, amelyet az 1150/2012. (V. 15.) kormányhatározat hozott létre. A bizottságnak ugyan csak egy tagja a honvéd vezérkar főnöke, de a bizottság tárcaközi jellege miatt a tudományos és a tematikus munkabizottságokban (például ár- és belvizek elleni munkabizottság vagy nukleárisbaleset-elhárítási, védekezési munkabizottság) a honvédelem képviseltetheti magát.

A legerősebb kapcsolódási pontról a 290/2011. (XII. 22.) kormányrendelet "gondoskodik”. A honvédelemről és a Magyar Honvédségről, valamint a különleges jogrendben bevezethető intézkedésekről szóló végrehajtási jogszabály leírja, hogy a polgári veszélyhelyzeti tervezés magába foglalja a védelmi igazgatás rendszerében megvalósuló közös civil-katonai tervezési rendszert, és a honvédelemért felelős miniszter gondoskodik a polgári veszélyhelyzeti tervezés kato- 
nai feladatainak koordinálásáról. A jogszabály részletekbe menően előírja a fegyveres összeütközések időszakában végrehajtandó polgári védelmi feladatokra történő felkészülést, valamint a megyei, a fővárosi és a helyi védelmi bizottságok (ezek titkárát a honvédelmi miniszter delegálja) és a katasztrófavédelem feladatait, utóbbit a BM felelősségébe utalva. Az oktatási felkészítés szervezése a BM feladata, de a képzéseket honvédelmi szakértők tartják.

A polgári védelem tervezése két pilléren nyugszik: egyfelől az általános polgári védelmi terveken (rendkívüli vagy szükségállapot idején végrehajtandó polgári védelmi feladatok), másfelől a veszélyelhárítási terveken (veszélyhelyzet, illetve a megelőző védelmi helyzetben végrehajtandó polgári védelmi feladatok). „A két tervfajta közötti - nem tartalmi - különbség, hogy a veszélyelhárítási tervek lentről felfelé építkeznek és nyílt minősítésűek, az általános polgári védelmi tervek készítése pedig ellenkező irányú és minősítésük titkos." (katasztrofavedelem.hu). Tartalmi különbség, hogy utóbbit a területi vagy az üzemi egységnél jellemző kockázatra kell kidolgozni, míg előbbit az alaptörvényben rögzített állapotra való felkészülésre. Ezeket a terveket legalább évente felülvizsgálják és frissítik.

A területfejlesztéssel való összehangolás szempontjából elengedhetetlen a katasztrófavédelem területi szerveződésének vizsgálata is. Területi egységeit tekintve a katasztrófavédelem szorosan kötődik a közigazgatás téregységeihez, „központi, területi, helyi és települési szinteken valósul meg” (Vinczéné Mészáros 2009, 430.). A helyi, megyei, fővárosi védelmi bizottság (ezek a katasztrófavédelem területi egységei) szervezi a közigazgatási szervek „területi szintű együttműködését, kidolgozza a katasztrófavédelemmel összefüggő tervezési, szervezési, felkészítési szakmai elveket és követelményeket, végzi a lakosság és az anyagi javak mentésével kapcsolatos tervező, szervező feladatokat, irányítja az alárendelt szerveknek a bekövetkezett események következményeinek felszámolására irányuló tevékenységét" (Mógor 2012, 5.). Ezek a területi bizottságok kidolgozhatnak még kölcsönös segítségnyújtási terveket is más megyékkel és a fövárossal kötött megállapodások alapján. Ehhez és az alapvető tervezői tevékenységükhöz az érintett szervektől, így a honvédségtől is adatokat gyüjtenek be, amelyeket a megkeresett szervnek kötelezően át kell adnia.

A területi szintek tehát akár el is térhetnek a területfejlesztési tervezési egységektől, amelyek nem mindig igazodnak a közigazgatási egységekhez (lásd helyi akciócsoportok vidékfejlesztési tervei vagy a statisztikai-tervezési régiók programjai), így összehangolásuk is nehézségekbe ütközik. Az eltérő szintekből adódó tervezői feszültségek előreláthatóan a jövőben sem fognak megoldódni, hiszen újból bevezették a járást mint közigazgatási középszintet - és várhatóan a katasztrófavédelem is kialakítja az ehhez társuló egységét -, a területfejlesztés viszont kistérségi hatáskör maradt, ami eltérő területbeosztást jelent.

További akadály, hogy a katasztrófavédelem - valószínűleg erőforrás-koncentrációs okokból - csak kemény kockázatokat kezel, csak olyanokat, amelyek bekövetkezésük esetén közvetlen (élet)veszélyt jelentenek. Ezek a következők: 
- elemi csapások, természeti eredetű veszélyek (árvíz, belvíz, rendkívüli időjárás, földtani veszélyforrások: földrengés, földcsuszamlás, beszakadás, talajsüllyedés, partfalomlás);

- ipari szerencsétlenség, civilizációs eredetű veszélyek (a katasztrófavédelmi törvény IV. fejezetének hatálya alá tartozó üzem, más létesítmény [ipari, mezőgazdasági] általi veszélyeztető hatás, veszélyes anyag szabadba kerülésének kockázata, távolság nukleáris létesítménytől; közlekedési útvonalak és csomópontok esetében: veszélyes áruk szállítása, jelentős forgalom; a katasztrófavédelmi törvény IV. fejezetének hatálya alá nem tartozó, katonai célból üzemeltetett veszélyes anyagokkal foglalkozó üzemek, veszélyes anyagokkal foglalkozó létesítmények);

- egyéb eredetű veszélyek (felszíni és felszín alatti vizek [elsősorban az ivóvízbázisok] sérülékenysége, humán járvány vagy járványveszély, valamint állatjárvány, a riasztási küszöböt elérő mértékủ légszennyezettség);

- kritikus infrastruktúrákkal kapcsolatos kockázatok (Mógor 2012 alapján).

Tehát a katasztrófavédelem tevékenysége nem terjed ki olyan puha tényezőkre, amelyek a biztonság fogalmának tág értelmezésébe beletartoznak és a területfejlesztés fontos céljai (pl. humánerőforrás- és gazdaságfejlesztés).

A jogszabályi kötelezettségek hiánya miatt a katasztrófavédelem is önállóan, elszigetelten tervez, de ez fordítva is igaz, hiszen kevés olyan pontot lehet felmutatni, ahol valóban megvalósul a három terület összekapcsolása. Mintaértékủ e tekintetben Az épített környezetről szóló (1997. évi LXXVIII.) törvény, amely elöírja az önkormányzatoknak, hogy a településrendezési terv esetében pontosan meg kell határozni a rendezési területet és a fejlesztés célját, az érintetteknek pedig - így a katasztrófavédelemnek is - 15 napja van a véleményezésre (csongrad.katasztrofavedelem.hu). A véleményező katasztrófavédelmi igazgatóság a terveket tűzvédelmi szempontok alapján vizsgálja, például a megközelíthetőség és a felvonulási terület biztonsága szempontjából.

\section{Javaslatok a biztonsági szempontok beépítésére a területi tervezési rendszerbe}

A területfejlesztés biztonságpolitikai összefüggései ágazati és területi anyagainkban nem kerülnek felszínre, ezáltal a tervezés jelentős eszköz- és érvrendszert hagy figyelmen kívül. A biztonsági szempontok fejlesztéspolitikába történő beemelését az alábbi érvek támasztják alá:

- A tervezési szakma foárama által elfogadott, hogy adott program/projekt szükségességét, indokoltságát részletesen be kell mutatni. E vizsgálat egyik részeleme lehetne a biztonság tényezőinek bemutatása, ezzel megalapozva a tervezett intézkedések fontosságát, és elmaradásuk esetén a nagyobb kockázatot. Akár a támogathatóságot is eldöntheti a koc- 
kázatok felmérése és új kockázatelemző módszerekkel való vizsgálata a stratégiákban és a projektekben. Jó példa erre a gazdaságfejlesztés területe, hiszen a gazdaság egészét és annak fejlesztését a függőség mikro- és makroszinten egyaránt meghatározza, amely függőség az ellátásbiztonság miatt biztonságpolitikai alapkérdés. Itt kell megjegyeznem, hogy a gazdaság globális összefüggésrendszere hasonló mintát, logikát követ, mint a globális-nemzetközi biztonságpolitika.

- A területfejlesztési tervezés során ha készül is közép- vagy hosszú távú forgatókönyv a döntések alátámasztására, megalapozására, a tervezők mindig a „legjobb” szcenáriót választják; ennek hátterében pedig közpolitikai, támogatottsági tényezőket találhatunk. A „legrosszabb” esetre, amikor a biztonsági tényezők szélsőséges helyzetei eltérítik a kívánt jövőt a megvalósuló jövőtől, nem készülnek vészforgatókönyvek, holott a felkészülés, a döntés-előkészítés igényelné azt.

- A vészforgatókönyvi tervezés az intézményi összehangolások sarokköve lehet. Ennek feltétele a biztonságpolitikai (beleértve a katasztrófavédelmet) és területfejlesztési tervezés kötelező intézményi összehangolásának kialakítása, amely lehetővé teszi a közös munka eredményeinek vonatkozó tervekbe és gyakorlatba való beépítését. Meg kell határozni a „felek” feladatrendjét és hatáskörét, az együttműködési rendszerét adó jogszabályi hátteret, továbbá az oktatás, a (tovább)képzés, valamint a kutatás területén való kapcsolódásokat.

- Az előző pontok logikájának fordítottját jelenti a biztonsági tényezők beemelése az értékelési szempontrendszerbe, amely akár kétirányú is lehet. Ez egyfelől jelentheti adott program/pályázat kezelőjének célrendszerét és elvárásait bírálati szempontrendszerként, másfelől viszont az adott program/projekt indikátorai között is lehet szerepeltetni biztonsági tényezőket, így a monitoringrendszer által mérhető eredményt lehet felmutatni. Természetesen a két lépés akár egyidejüleg is megvalósítható.

- A fejlesztési tervezés során szintén kiemelten fontos a partnerség és az érintettek feltárása, ily módon feltárhatóak a párhuzamos vagy ellentétes érdekeltségek. A biztonságpolitika szereplői is beilleszthetőek ebbe a rendszerbe. Párhuzamos érdekeltség esetén az együttműködés valós eszköz- és erőforrás-bővüléssel jár, ami bevonható a fejlesztésbe. Ellenérdekeltség esetén olyan, a program hatásfokát csökkentő tényező kerül napvilágra (és ezzel kezelhetővé is válik), amely akár a fejlesztés eredeti célkitűzésének elérését veszélyeztetheti.

- Az erőforráskerettel is számolni kell. A biztonságpolitika szereplői a területfejlesztés által fel nem fedezett eszközrendszerrel rendelkeznek. Együttmüködésben (akár nemzetközi dimenzióban) ezek egy része bevonható a fejlesztésbe. Megjelenési formája lehet többlet pénzügyi forrás vagy a megvalósításba bevonható, a biztonságpolitika szereplői által 
használt fizikai infrastruktúra és eszközállomány, mely utóbbi természetéből fakadóan gyakran fejlett, csúcstechnológiát felmutató eszköz.

- Az erőforrások - közülük is az infrastruktúrák térbeli megjelenése - szintén feladatokat adhatnak a tervezőknek. Ez, ahogy már korábban utaltam rá, fontos kapcsolódási pont: meg kell vizsgálni, hogyan befolyásolják a helyi gazdaságot a védelemi intézmények, lehet-e „telepíteni rájuk” ipart, szolgáltatási ágazatot. A biztonságpolitikai fejlesztések segithetik a helyi gazdaságfejlesztést, de nehéz helyzetbe is hozhatják átcsoportosítás, leépítés stb. esetén. Az innováció terjedésével és az oktatásszervezéssel kapcsolatban is felmerülhetnek párhuzamok, hisz az igazán korszerü és fejlett technológiát alkalmazó védelmi ágazatok igényei megjeleníthetők e területek fejlesztéseiben. A biztonság- és a területfejlesztési tervek között tehát indokolt a szinergia kialakítása. Ezt a szinergiát területi szintenként kell megteremteni, mivel különböző léptékeken különböző kapcsolódási pontok mutathatók ki (pl. egy megyei fejlesztés során több szomszédos megye védelmi alintézmény együttesen is kiszolgálható, míg a helyi kapcsolódási pont egy más ágazat fejlesztésére koncentrálhat).

Gyakran észre sem vesszük, de a fejlesztési programok elemeinek többsége szerepel a biztonsági stratégiák támogatandó területei között is. Bár nehézséget okoz, hogy a „másik oldal” eltérő területi léptéket alkalmaz - főleg közigazgatási egységeket -, de a lehetőségeket „bűn lenne” kihagyni a tervezésből, számításból. Mindez persze a gyakorlatban azt jelenti, hogy az eddig ismert ún. horizontális fejlesztéspolitikai elemek (pl. esélyegyenlőség, fenntarthatóság) közé szükséges lenne beemelni a „biztonsági elemet” is, ahogyan azt az OTK (13. o.) tartalmazza. A jelenlegi tervezésben használt veszélyek nevesítése, a veszélykezelés ugyanis oly mértékben parciális, hogy a tervek, projektek kevéssé tudnak hozzájárulni a biztonság magasabb fokának eléréséhez. Fejlesztési utakat keresünk, ugyanakkor azokat az irányokat kellene választanunk, amelyek a biztonságot is nagymértékben erősítik. Ehhez az kell, hogy a biztonságvédelem, katasztrófavédelem és a területfejlesztés ágazati és területi rendszerei legyenek összehangolva (jelenleg nincsenek); ezt a kapcsolódást pedig a katasztrófavédelmen keresztül lehet kialakítani.

Végezetül érdemes felhívnom a figyelmet egy „valós veszélyre” a biztonsági szempontokat figyelembe vevő tervezés kapcsán. A biztonság fogalmának szubjektív volta miatt akár áteshetünk a ló túlsó oldalára is. A kockázat elsősorban a veszélyeztetettség mértékét fejezi ki, ugyanakkor problémát jelent, hogy a biztonság egyaránt megközelíthető objektíven (reális kockázat) és szubjektíven (kockázatpercepció), és nem szavatolja semmi, hogy e két megközelítés mindig egybeesik. Ez pedig lehetővé teszi olyan kérdések „biztonságossá tételét” is, amelyek valójában nem jelentenek létfenyegetettséget, azonban bizonyos szubjektív tényezők hatására mégis „biztonságossá tehetők”(Gazdag, Tálas 2008). 


\section{Jegyzetek}

1 A körültekintő döntéshozatal számára szempontok még, hogy a növekvő terület- és növényanyagigény emeli a beruházás költségét, de az agráriumtól is „felesleges” termőterületet vonhat el.

2 Megvizsgált dokumentumok: USA - National security strategy, 2010; The national security strategy of the United Kingdom - Security in an interdependent world, 2010; Strategic concept for the defence and security of the members of the North Atlantic Treaty Organisation, 2010; EU internal security strategy, 2010; Jelentés az európai biztonsági stratégia végrehajtásáról, 2009; Magyarország nemzeti biztonsági stratégiája, 2012; Magyarország külkapcsolati stratégiája, 2009; Magyar külpolitika - Külpolitika az Uniós elnökség után, 2011.

3 Részletes vizsgálatok nélkül persze nem zárható ki teljesen annak lehetősége, hogy egy-egy dokumentum egységbe foglalva tartalmazza a tág biztonságértelmezést, de a fejlesztési rendszer jellemzői a fentiek szerint mindenképpen leírhatóak.

4 A 71/2006. (IV. 3.) kormányrendelet 2. § e) bekezdése szerint „védelmi igazgatás: a közigazgatás részét képező feladat és szervezeti rendszer. Az állam komplex védelmi feladatainak megvalósítására létrehozott, valamint e feladatra kijelölt közigazgatási szervek által végzett végrehajtó, rendelkező tevékenység, amely magába foglalja az Alkotmányban szabályozott minősített időszakokra és az azokat kiváltó helyzetekre történő felkészülést, továbbá az említett időszakok és helyzetek honvédelmi, polgári védelmi, katasztrófavédelmi, védelemgazdasági, lakosság ellátási feladatainak tervezésére, szervezésére, a feladatok végrehajtására irányuló állami tevékenységek összességét" (Csontos 2009, 6.).

5 Érdekesség a végrehajtás összehangolásáról a vörösiszap-katasztrófa kapcsán: „A HM Tervezési és Koordinációs Főosztály és a HM Védelmi Hivatal által felváltva vezényelt Kormányközi Koordinációs Bizottság (KKB) Operatív Törzsbe delegált ágazati összekötők 2010. október 19én 20.00-ig biztosították az MH Katasztrófavédelmi Operatív Bizottság folyamatos együttmüködését a felsőszintű országos vezetéssel. A továbbiakban otthonukban láttak el készenléti szolgálatot. Meg kell említeni, hogy feltétlenül szükségesnek látszik a tevékenység irányításának tisztázása, hiszen a Veszprém Megyei Védelmi Bizottság mellett a KKB is irányított, ami néha ellentmondást okozott." (Borsos 2011, 32.)

\section{Irodalom}

1035/2012. (II.21.) kormányhatározat Magyarország Biztonságpolitikai Stratégiájáról

1150/2012. (V. 15.) kormányhatározat A Katasztrófavédelmi Koordinációs Tárcaközi Bizottság létrehozásáról 1997. évi LXXVIII. törvény Az épitett környezet alakitásáról és védelméról 2009. évi XXXVII. törvény Az erdőról, az erdő védelméröl és az erdögazdálkodásról 2011. évi CXXVIII. törvény A katasztrófavédelemról és a hozzá kapcsolódó egyes törvények módositásáról 290/2011. (XII. 22.) kormányrendelet A honvédelemról és a Magyar Honvédségröl, valamint a különleges jogrendben bevezethetö intézkedésekról szóló 2011. évi CXIII. törvény egyes rendelkezéseinek végrehajtásáról 96/2005. (XII. 25.) országgyúlési határozat Az Országos Fejlesztéspolitikai Koncepcióról 97/2005. (XII. 25.) országgyủlési határozat Az Országos Területfejlesztési Koncepcióról

Barry B., Ole W., Jaap de W. (2006): A biztonsági elemzés új keretei. In: Póti L. (szerk.) Nemzetközi Biztonsági Tanulmányok. Zrínyi Kiadó, Budapest, 53-112.

Borsos J. (2011): A HKR vezetési, irányítási rendje annak aktivizálása időszakában. In: Isaszegi L. (szerk.): A katasztrófavédelem aktuális kérdései. Zrínyi Média Közhasznú Nonprofit Kft., Budapest, 28-33.

Buzan, B., Wæver, O., de Wilde, J. (2006): A biztonsági elemzés új keretei. In: Póti L. (szerk.): Nemzetközi biztonsági tanulmányok. Zrínyi Kiadó, Budapest, 53-112.

Csontos A. (2009): Védelmi tervezési ismeretek védelmi igazgatási vezetók számára. Zrínyi Miklós Nemzetvédelmi Egyetem, Budapest 
Deák P. (szerk.) (2007): Biztonságpolitikai kézikönyv. Osiris, Budapest

Fi I. (2002): Utak és környezetük tervezése. BME, Budapest

Gazdag F. (szerk.) (2001): Biztonságpolitika. SVKH, Budapest

Gazdag F., Tálas P. (2008): A biztonság fogalmának határairól. Nemzet és Biztonság: Biztonságpolitikai Szemle, 1., 3-9.

Hideg É., Nováky E. (2008): A jövőhöz való viszony és változása Magyarországon. Magyar Tudomány, 9., $1125-1135$.

http://consilium.europa.eu/uedocs/cmsUpload/031208ESSIIHU.pdf Letöltés: 2012. február 10.

http://csongrad.katasztrofavedelem.hu/index.php?subpage=3\&subpage1=135 Letöltés: 2013. január 15

http://eu.kormany.hu/download/4/c6/20000/kulpolitikai_strategia_20111219.pdf Letöltés: 2012. február 1.

http://kertesz.blog.hu/2013/03/18/kaosz_havazas_vederdo Letöltés: 2013. március 21.

http://register.consilium.europa.eu/pdf/hu/10/st05/st05842-re02.hu10.pdf Letöltés: 2012. február 12.

http://www.biztonsagpolitika.hu/documents/1291766875_NATO_Strat_Koncepcio_2010_hun_BSZK.pdf Letöltés: 2012. február 10.

http://www.biztonsagpolitika.hu/index.php?id=16\&aid=1039\&title=Biztons\%C3\%A1gias\%C3\%ADt\%C3\%A1s_Securitisation Letöltés: 2012. március 10.

http://www.consilium.europa.eu/ueDocs/cms_Data/docs/pressdata/HU/reports/104644.pdf Letöltés: 2012. február 14.

http://www.katasztrofavedelem.hu/index2.php?pageid=kozigazgatas_felkeszites_polgmester_tervezes Letöltés: 2013. január 15.

http://www.katasztrofavedelem.hu/letoltes/szervezet/BM_OKF_alapito_okirat_20120328.pdf Letöltés: 2013. január 15.

http://www.kulugyminiszterium.hu/kum/hu/bal/Kulpolitikank/kulkapcsolati_strategia/Letöltés: 2012. február 1.

http://www.number10.gov.uk/news/national-security-strategy/ Letöltés: 2012. február 10.

http://www.whitehouse.gov/sites/default/files/rss_viewer/national_security_strategy.pdf Letöltés: 2012. február 10.

Kunos B. (2008): A védelem makroszintü tervezése és a (HM) Tárcaszintű Védelmi Tervezőrendszer. Előadás. Pécsi Tudományegyetem, Pécs.

Mógor J. (2012):Az új katasztrófavédelmi szabályozás. Jegyzet és jogszabálygyüjtemény közbiztonsági referensek felkészitéséhez. BM OKF, Budapest

Vinczéné Mészáros Cs. (2009): A védelmi igazgatás rendszere. Hadmérnök, 2., 430-436. 


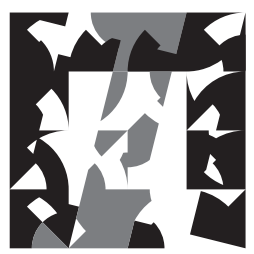

TÉR ÉS TÁRSADALOM | SPACE AND SOCIETY 